\title{
EFFECTS OF STRUCTURAL VARIATIONS ON THE HYDROGEN BOND PAIRING BETWEEN ADENINE DERIVATIVES AND THYMINE*
}

\author{
Valia Nikolova, Boris Galabov \\ Department of Chemistry and Pharmacy, University of Sofia, \\ 1 James Bourchier Blvd Sofia 1164, Bulgaria \\ ohtvd@chem.uni-sofia.bg; galabov@chem.uni-sofia.bg
}

\begin{abstract}
The hydrogen bonding between substituted adenines and thymine was investigated by density functional theory computations at the B3LYP/6-311+G(2d,2p) level. The effect of 20 different polar substituents at position 8 in adenine was examined in detail. Three different theoretical parameters, reflecting the electrostatics at the atoms involved in hydrogen bonding, were applied. An excellent correlation between electrostatic potentials at the bonding atoms in the monomer adenines and interaction energies was derived (Eqn. 2). It can be employed in designing bioactive adenine derivatives that are able to bind with a finely adjusted strength to thymine bioreceptor sites. NBO and Hirshfeld atomic charges are found to be less successful as reactivity predictors in these interactions.
\end{abstract}

Keywords: DNA base pair; adenine; thymine; hydrogen bonding; electrostatic potential; atomic charges

\section{ЕФЕКТИ НА СТРУКТУРНИТЕ ВАРИЈАЦИИ ВРЗ СПАРУВАЊЕТО НА АДЕНИНСКИ ДЕРИВАТИ И ТИМИН СО ПОМОШ НА ВОДОРОДНО СВРЗУВАЊЕ}

Истражувано е водородното сврзување помеѓу супституирани аденини и тимин со помош на пресметки според теоријата за функционал на електронската густина на нивото B3LYP/6$311+\mathrm{G}(2 \mathrm{~d}, 2 \mathrm{p})$. Детално е изучуван ефектот на 20 различни поларни супституенти на аденин во позицијата 8. Применети се три различни теоретски параметри кои ја рефлектираат електростатиката на атомите вклучени во водородното сврзување. Добиена е одлична корелација помеѓу електростатските потенцијали на сврзувачките атоми во мономерните аденини и интеракционите енергии (р-ка 2). Тоа може да се примени при дизајнирање на биоактивни аденински деривати кои можат да се сврзат со фино нагодена јачина со тиминските биорецепторски сајтови. Најдено е дека т.н. NBO и Хиршфилдовите (Hirshfeld) атомски полнежи се помалку успешни како претскажувачи на реактивноста во овие интеракции.

Клучни зборови: ДНК базен пар; аденин; тимин; водородно сврзување; електростатски потенцијал; атомски полнежи

- Dedicated to Academician Gligor Jovanovski on the occasion of his $70^{\text {th }}$ birthday. 


\section{INTRODUCTION}

Hydrogen bonding [1-4] plays a key role in various biological processes, including pairing of nucleobases [4, 6], protein folding [7, 8], enzyme catalysis $[9,10]$, and other interactions in biosystems. Hydrogen bonding influences the solubility of biologically active ligands and the way they bind to bioreceptors [11]. Quantitative characterization of the ability of biological receptors (nitrogen bases in nucleic acids, amino acid units in proteins) to form hydrogen bonds is, therefore, of particular importance in the design of bioactive structures. Experimental and theoretical investigations on hydrogen bonding involving structural fragments of biopolymers are the subject of continuing interest [12-15]. Literature data reveal that structurally modified DNA bases may possess substantial biological activity [16-28]. For example, halogenated pyrimidines have been shown to possess well-expressed anti-tumor, anti-bacterial and anti-viral effects [20]. In the molecular design of drugs, substituted nucleic acids are used to enhance the stability of DNA pairs [21]. Analyzing in detail the influence of structural variations on biological activity can also provide information on the mechanisms of action of bioactive molecules.

Hobza et al. [22-24] applied high-level theoretical computations in evaluating the hydrogen bond interaction energies for pairs of DNA bases. Historically, hydrogen bonds were considered to be mostly electrostatic in nature [25-32]. It has been shown, however, that a number of alternative quantum mechanical terms also contribute to the overall hydrogen bond energies. Thus, the overall interaction energy is a complex function of several terms: electrostatic, charge-transfer, dispersive, quantum exchange as well as smaller contributions from higher order terms [33-38]. Bickelhaupt et al. $[33,34]$ showed that Watson-Crick base-pair interactions associated with the charge transfer from the free electron pair of $\mathrm{O}$ or $\mathrm{N}$ to $\mathrm{NH} \sigma^{*}$ acceptor orbital of the other base is comparable in magnitude to the electrostatic interaction.

Kawahara et al. [21], Bickelhaupt et al. [3335], and Meng et al. [40-42] examined by theoretical computations the effect of substituents on the hydrogen bonding of modified DNA base pairs. Bickelhaupt et al. [35, 39] investigated how the strength and length of hydrogen bonds is influenced by the introduction of $\mathrm{F}, \mathrm{Cl}$, and $\mathrm{Br}$ substituents at position 8 in the purine (Scheme 1) and at position 6 of the pyrimidine nucleobases. The same authors analyzed in particular [34] the impact of substituents $\left(\mathrm{NH}, \mathrm{NH}_{2}, \mathrm{NH}_{3}{ }^{+}, \mathrm{O}^{-}, \mathrm{OH}\right.$, and $\left.\mathrm{OH}_{2}{ }^{+}\right)$ at position 8 in the purine ring and in position 6 in the pyrimidine cycle on interaction energies for hydrogen-bonded complexes of substituted guanines with cytosine derivatives. Meng et al. [4042] investigated the effect of $\mathrm{CH}_{3}, \mathrm{CH}_{3} \mathrm{O}, \mathrm{F}$, and $\mathrm{NO}_{2}$ substituents on the adenine-thymine base pairing.

Popelier et al. [43] examined by theoretical DFT computations at the B3LYP/6-311+G(2d,p) level the effects of 42 substituents on the interaction energy of the cytosine-guanine base pairs. They considered the influence of both electronwith drawing and electron-accepting substituents on positions 5 and 6 in cytosine. As expected, the presence of electron-accepting substitutuents leads to less stable base pairs with guanine. These authors established correlations between interaction energies and reactivity descriptors, derived from analysis of quantum chemical topology (QCTdescriptors). Later, the same authors [44] examined how the interaction energies between the same guanine-cytosine base pairs vary under the influence of substituents at position 8 of guanine.

In the present research, we apply alternative theoretical descriptors - electrostatic potential at nuclei (EPN) and atomic charges - in analyzing the relationships between structural variations in adenine and hydrogen bonding for the adeninethymine base pair.

\section{COMPUTATIONAL DETAILS}

Density functional theory (DFT) computations at the B3LYP/6-311+G (2d, 2p) level [45-47] for a set of 20 hydrogen-bonded adenine-thymine complexes, containing various substituents at position 8 of adenine were performed. All computations employed the Gaussian 09 program [48]. Optimized structures were verified to be minima of the potential energy surfaces with the aid of harmonic frequency computations. The interaction energies are corrected for basis set superposition error (BSSE) using the counterpoise method [49].

The electrostatic potential at nuclei was first introduced by Wilson [50]. Politzer and Thruhlar [51] defined the electrostatic potential at nuclei $Y$ $\left(V_{Y}\right)$ by Eqn. (1):

$$
V_{\mathrm{Y}} \equiv V\left(\mathbf{R}_{\mathrm{Y}}\right)=\sum_{A(\neq Y)} \frac{Z_{A}}{\left|\mathbf{R}_{A}-\mathbf{R}_{Y}\right|}-\int \frac{\rho(\mathbf{r})}{\left|\mathbf{r}-\mathbf{R}_{\mathrm{Y}}\right|} d \mathbf{r}
$$

In this relationship, the singular term for nucleus $Y$ is excluded. $Z_{A}$ is the charge of nucleus $A$ at position $\mathbf{R}_{A}$, and $\rho(\mathbf{r})$ is the electron density func- 
tion. Following the original findings [53-57] that EPN values define quantitatively the ability of molecules to form hydrogen bonds, the EPN index was extensively applied in describing both hydrogen bonding and chemical reactivity of various molecular systems [58-65]. In a recent review, we surveyed the application of EPN in quantifying various molecular properties of aromatic systems [62]. In contrast to other theoretical parameters that characterize local molecular properties such as atomic charges, the electrostatic potential at nuclei is a rigorously defined quantum mechanical quantity. The 1/r dependence of EPN (Eqn. 1) determines considerably greater contributions to $V_{Y}$ of negative and positive charges in close vicinity of nucleus $Y$ when compared with longer distance charge variations resulting from structural alterations [63].

\section{RESULTS AND DISCUSSION}

As is known, hydrogen bonds in the adenine-thymine base pair are formed between the hydrogen atom from the amino group of adenine and the carbonyl oxygen atom of thymine, and between the N3-H hydrogen atom in thymine and the free electron pair at the N1 nitrogen atom in adenine (Scheme 1). We examined a set of 20 complexes of substituted at position 8 adenine derivatives with thymine (Scheme 1).

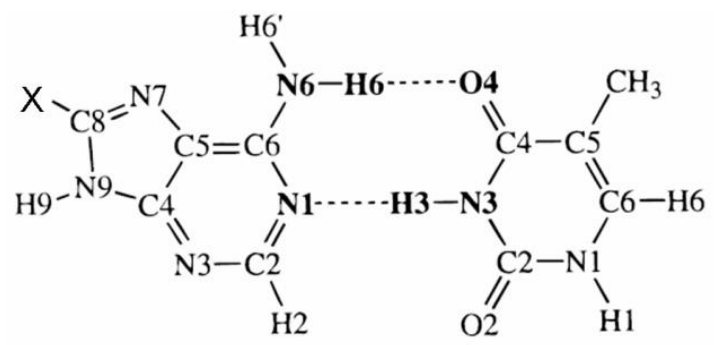

Scheme 1

$\mathrm{X}=\mathrm{H}, \mathrm{CH}_{3}, \mathrm{OC}_{2} \mathrm{H}_{5}, \mathrm{OCH}_{3}, \mathrm{OH}, \mathrm{NH}_{2}, \mathrm{~N}\left(\mathrm{CH}_{3}\right)_{2}, \mathrm{~F}, \mathrm{Cl}, \mathrm{Br}$, $\mathrm{CCH}, \mathrm{CHO}, \mathrm{CCl}_{3}, \mathrm{COCH}_{3}, \mathrm{CF}_{3}, \mathrm{COCl}, \mathrm{CN}, \mathrm{COF}, \mathrm{NO}_{2}, \mathrm{NO}$

In this research, we conducted quantum mechanical computations aiming at quantifying the effects of structural variations in adenine on the hydrogen bonding interaction (pairing) with thymine. As already discussed in the introductory section, derivatives of the nucleobases have been shown to possess biological activities and potential for clinical applications [16-28]. It was also of interest to analyze the impact of structural changes on the geometries of the formed complexes. We focused on evaluating parameters describing the variations in electrostatic properties in the adenine moiety at the hydrogen bonding sites. In an earlier study, we demonstrated [57] by applying Morokuma energy decomposition analysis [29, 66-68] that the different quantum mechanical terms contributing to hydrogen bonding energies correlate almost perfectly with the electrostatic energy term. Thus, it is anticipated that parameters, characterizing molecular electrostatics, can be successfully employed in discussing the hydrogen bonding between nucleobases. Since the base pair complexes are formed at particular atomic centers in the molecules, quantities associated with properties of individual atomic sites are appropriate in examining these interactions. We evaluated with the aid of DFT computations three types of electronic parameters: natural bond orbital (NBO) charges [69], Hirshfeld atomic charges [70], and electrostatic potentials at the nuclei (EPN). It should here be underlined that, as expressed in Eqn. 1, the EPN values $\left(V_{Y}\right)$ depend on both electron density and all positive nuclear charges in a molecule. Thus, variations in the nuclear charges of the distant substituent $X$ may affect the $V_{Y}$ value at the hydrogen bonding sites. Nevertheless, the dominant contributions to $V_{Y}$ come from the immediate neighborhood of atom $Y$ as result of the $1 / r$ dependence in Eqn. 1. Since the atoms in the vicinity of N1 and N6 atoms in adenine remain the same throughout the investigated series (Scheme 1), it can be considered that the shifts of $V_{Y}(Y=\mathrm{N} 1, \mathrm{H} 6)$ upon the distant structural variations (at position C8) are dominated by electron density variations near atoms $Y$. Numerous successful application of EPN as a reactivity index for hydrogen bonding and chemical reactivity confirm the credibility of this hypothesis [53-65].

Figure 1 illustrates key geometrical parameters of some optimized complexes. In Table 1, the shifts of interaction energies $(\Delta \Delta E)$ with respect to the unsubstituted adenine-thymine base pair (see footnotes to Table 1) are juxtaposed to the estimated lengths of the two formed hydrogen bonds. While the shifts of interaction energies between the different complexes as induced by the polar substituents at position 8 of adenine are rather small, the changes in hydrogen bond lengths are substantial. The variation of the N...H length reaches about $0.06 \AA$ and the O...H hydrogen bond length varies within $0.04 \AA$. As expected, very good correlations between interaction energies and variations of hydrogen bond lengths are obtained. Figure 2 illustrates these dependences. 

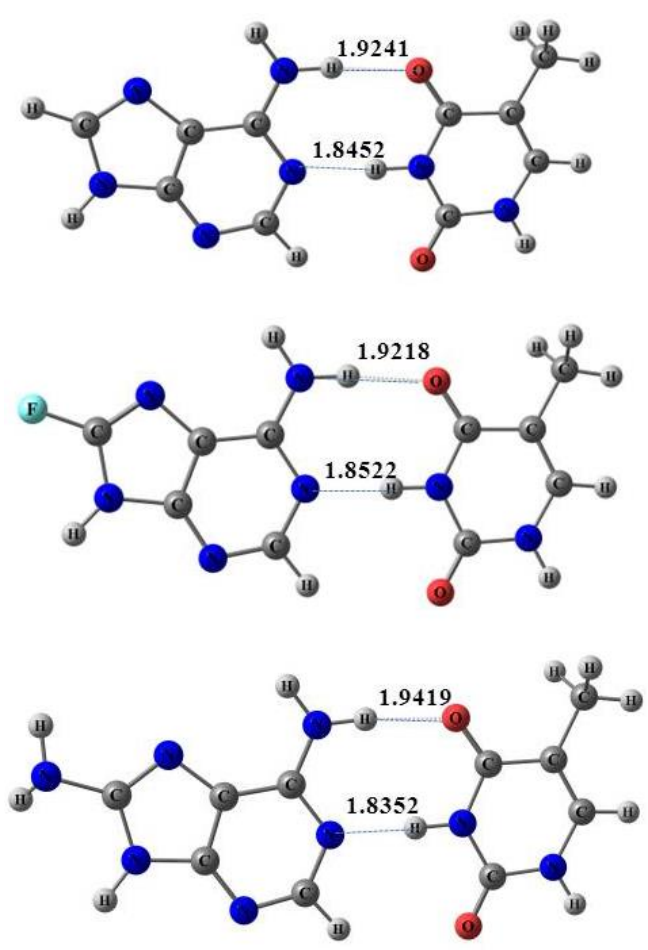

Fig. 1. Optimized structures of selected hydrogen-bonded complexes between substituted adenines and thymine

Table 1

B3LYP/6-311+G(2d,2p) calculated values of corrected energy of hydrogen bonding $\left(\Delta \boldsymbol{E}^{\text {corr }}, \mathrm{kcal} / \mathrm{mol}\right)$, effects of substituents in position $C^{8}$ in the adenine heterocycle on interaction energies $(\Delta \Delta \boldsymbol{E}, \mathrm{kcal} / \mathrm{mol})$, and hydrogen bond lengths $(A)$ in the complexes of adenine derivatives with thymine

\begin{tabular}{|c|c|c|c|c|}
\hline Substituent & $\Delta E^{\text {corr }}$ & 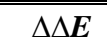 & $r_{\text {H...O }}$ & $\boldsymbol{r}_{\mathrm{N} \ldots \mathrm{H}}$ \\
\hline H & -11.579 & 0.000 & 1.924 & 1.845 \\
\hline $\mathrm{CH}_{3}$ & -11.500 & 0.079 & 1.935 & 1.838 \\
\hline $\mathrm{OC}_{2} \mathrm{H}_{5}$ & -11.365 & 0.213 & 1.937 & 1.839 \\
\hline $\mathrm{OCH}_{3}$ & -11.382 & 0.197 & 1.937 & 1.838 \\
\hline $\mathbf{O H}$ & -11.378 & 0.201 & 1.936 & 1.842 \\
\hline $\mathrm{NH}_{2}$ & -11.355 & 0.223 & 1.942 & 1.835 \\
\hline $\mathbf{N}\left(\mathrm{CH}_{3}\right)_{2}$ & -11.290 & 0.289 & 1.949 & 1.830 \\
\hline $\mathbf{F}$ & -11.524 & 0.055 & 1.922 & 1.852 \\
\hline Cl & -11.571 & 0.008 & 1.918 & 1.854 \\
\hline $\mathrm{Br}$ & -11.588 & -0.009 & 1.920 & 1.853 \\
\hline $\mathrm{CCH}$ & -11.636 & -0.057 & 1.919 & 1.849 \\
\hline CHO & -11.806 & -0.227 & 1.900 & 1.864 \\
\hline $\mathrm{CCl}_{3}$ & -11.757 & -0.178 & 1.905 & 1.860 \\
\hline $\mathrm{COCH}_{3}$ & -11.718 & -0.139 & 1.910 & 1.858 \\
\hline $\mathrm{CF}_{3}$ & -11.750 & -0.172 & 1.905 & 1.862 \\
\hline COCl & -11.912 & -0.333 & 1.888 & 1.870 \\
\hline $\mathbf{C N}$ & -11.857 & -0.278 & 1.896 & 1.868 \\
\hline $\mathrm{COF}$ & -11.913 & -0.334 & 1.890 & 1.869 \\
\hline $\mathrm{NO}_{2}$ & -11.947 & -0.368 & 1.884 & 1.876 \\
\hline NO & -11.983 & -0.404 & 1.884 & 1.873 \\
\hline \multicolumn{3}{|c|}{ Correlation coefficients $^{b}$} & 0.991 & 0.972 \\
\hline
\end{tabular}

${ }^{\mathrm{a}} \Delta \Delta \mathrm{E}(\mathrm{X})=\Delta E^{\mathrm{corr}}\left(\mathrm{A}^{\mathrm{X}}: \mathrm{T}\right)-\Delta E^{\mathrm{corr}}(\mathrm{A}: \mathrm{T})$.

${ }^{\mathrm{b}}$ Correlation coefficients for the relationships between $\Delta \Delta E$ and the lengths of hydrogen bonds in the substituted adenine complexes with thymine.

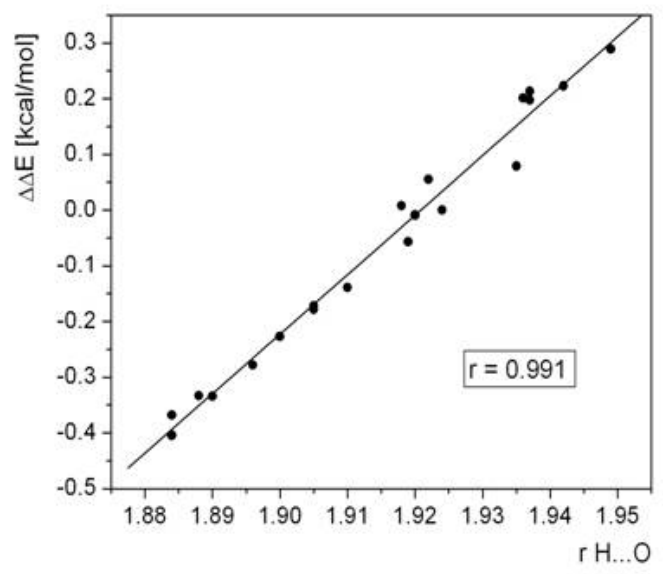

A

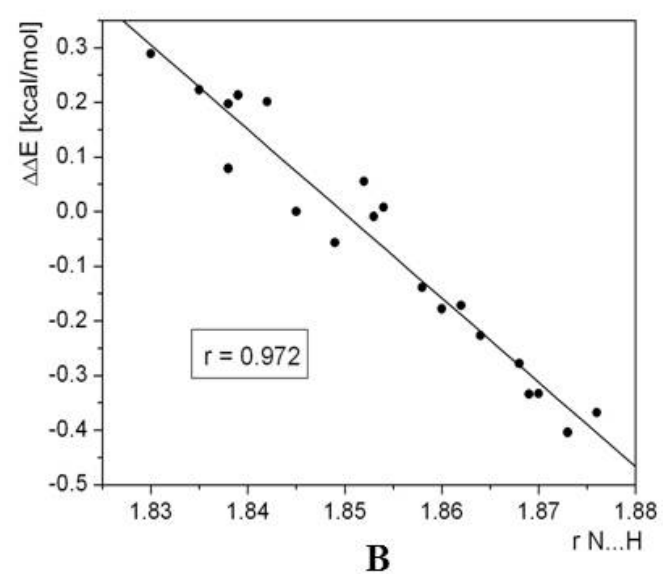

Fig. 2. Plots of variations of interaction energies $(\Delta \Delta E)$ vs. $r_{\mathrm{H} \ldots \mathrm{O}}(\mathbf{A})$ and $r_{\mathrm{N} \ldots \mathrm{H}}(\mathbf{B})$ hydrogen bond lengths in complexes of substituted at position 8 adenines with thymine

The principal focus in this research is to examine in detail the possible link between properties of monomeric ligands, in our case substituted at position 8 adenines, and hydrogen bonding energies of the formed complexes. Such relationship may facilitate the design of suitable bioactive ligands that would be able to bind to specific nucleic acid target sites. The thymine nucleobase in the present case has the role of a model bioreceptor. The introduction of substituents is an approach for fine-tuning the binding abilities of molecular ligands to the target bioreceptor sites. As mentioned, we evaluated three types of molecular parameters that are expected to quantify the reactivities of the substituted adenines in the studied interactions. In Table 2 we compare the estimated variations of interaction energies with the shifts of atomic electrostatic potentials $\left(\Delta V_{\mathrm{H} 6}, \Delta V_{\mathrm{N} 1}\right)$ at the N6-H6 hydrogen and $\mathrm{N} 1$ nitrogen atoms in monomeric adenines, as well as the changes of NBO and Hirshfeld atomic charges at the binding atomic sites. The definitions of terms are provided in the footnotes below Table 2 . 
As discussed, $\Delta \Delta E$ measures the effect of substituents at position 8 in Adenine on the energy of hydrogen-bonding. A negative value of $\Delta \Delta E$ means that the substituted complex is more stable than the unsubstituted base pair. Electrostatic potentials at nuclei for the monomeric adenines are obtained as standard option from Gaussian09 [48]. The shifts of EPN for the amino group hydrogen atom (Scheme 1) are given in column 3 of Table 1. For easier interpretation, the variations of EPN under the influence of substituents are presented as shifts of EPN with respect the value in the parent adenine molecule. A good correlation between $\Delta \Delta E$ and $\Delta V_{\mathrm{H} 6}$ is found. Figure 2 illustrates the plot between these quantities.

Since the base pairing involves simultaneous formation of two hydrogen bonds, a more relevant dependence should involve the EPN values at both $\mathrm{H} 6$ and $\mathrm{N} 1$ atomic centers. The following twoparameter equation linking $\Delta \Delta E$ with $\Delta V_{\mathrm{H} 6}$ and $\Delta V_{\mathrm{N} 1}$ in the monomeric adenines is obtained:

$$
\begin{gathered}
\Delta \Delta E=0.042 \Delta V_{\mathrm{H} 6}-0.061 \Delta V_{\mathrm{N} 1}+0.022 \\
n=20, r=0.993
\end{gathered}
$$

The obtained high correlation coefficient $(r$ $=0.993$, Eqn. 2) shows that the interactions energies for the hydrogen bond formation of substituted adenines with thymine can be quantitatively predicted from theoretically evaluated EPN values for the participating atoms in the monomeric adenines. Eqn. 2 may be successfully applied in designing ligands that would bind with an appropriate strength to thymine bioreceptor sites. The same level of theory [B3LYP/6-311+G(2d,2p)] should certainly be applied in such theoretical modeling if Eq. 2 is applied.

The estimated atomic charges at the same atoms are much less successful in predicting the hydrogen bonding energies. While the correlations between $\Delta \Delta \mathrm{E}$ and the shifts of atomic charges (against the values in the parent adenine) for H6 hydrogen are quite good for both Hirshfeld and NBO charges (see Figure 4 for the case of Hirshfeld atomic charges), no correlations with the N1 charges are established (see the correlation coefficients at the bottom of Table 2).

T a b le 2

B3LYP/6-311+G(2d,2p) calculated values for the shifts of $\Delta E^{\text {corr }}$ as induced by substituents at position 8 in adenine $(\Delta \Delta E, \mathrm{kcal} / \mathrm{mol})$, shifts of EPN at the H6 hydrogen atom $\left(\Delta V_{H 6}, \mathrm{kcal} / \mathrm{mol}\right)$ and at the N1 nitrogen

\begin{tabular}{|c|c|c|c|c|c|c|c|}
\hline Substituent & $\Delta \Delta E^{\mathrm{a}}$ & $\bar{c} \Delta V_{\mathrm{H} 6}{ }^{\mathrm{b}}$ & $\Delta V_{\mathrm{N} 1}^{\mathrm{b}}$ & $\overline{\Delta \Delta q^{\text {Hirsh }}(\mathrm{H} 6)^{\mathrm{c}}}$ & $\overline{\Delta \Delta q^{\text {Hirsh }}(\mathrm{N} 1)^{\mathrm{c}}}$ & $\Delta \Delta q^{\mathrm{NBO}}(\mathrm{H} 6)^{\mathrm{d}}$ & 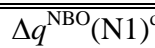 \\
\hline $\mathbf{H}$ & 0.000 & 0.00 & 0.00 & 0.0000 & 0.0000 & 0.0000 & 0.0000 \\
\hline $\mathrm{CH}_{3}$ & 0.079 & -3.18 & -2.50 & -0.0023 & -0.0011 & -0.0019 & 0.0003 \\
\hline $\mathrm{OC}_{2} \mathrm{H}_{5}$ & 0.213 & -5.65 & -3.43 & -0.0049 & 0.0003 & -0.0040 & 0.0042 \\
\hline $\mathrm{OCH}_{3}$ & 0.197 & -4.91 & -2.61 & -0.0046 & 0.0008 & -0.0038 & 0.0047 \\
\hline OH & 0.201 & -3.00 & -0.74 & -0.0022 & 0.0019 & -0.0020 & 0.0061 \\
\hline $\mathbf{N H}_{2}$ & 0.223 & -6.47 & -4.18 & -0.0050 & 0.0000 & -0.0040 & 0.0051 \\
\hline $\mathrm{N}\left(\mathrm{CH}_{3}\right)_{2}$ & 0.289 & -9.54 & -6.86 & -0.0070 & -0.0014 & -0.0058 & 0.0003 \\
\hline $\mathbf{F}$ & 0.055 & 2.82 & 4.31 & 0.0010 & 0.0045 & 0.0009 & 0.0074 \\
\hline Cl & 0.008 & 3.72 & 4.23 & 0.0020 & 0.0034 & 0.0017 & 0.0049 \\
\hline $\mathrm{Br}$ & -0.009 & 3.84 & 4.22 & 0.0021 & 0.0033 & 0.0018 & 0.0045 \\
\hline $\mathrm{CCH}$ & -0.057 & 3.31 & 2.53 & 0.0025 & 0.0008 & 0.0020 & 0.0003 \\
\hline CHO & -0.227 & 10,40 & 8.53 & 0.0074 & 0.0027 & 0.0055 & -0.0001 \\
\hline $\mathrm{CCl}_{3}$ & -0.178 & 7.78 & 6.68 & 0.0048 & 0.0032 & 0.0041 & 0.0020 \\
\hline $\mathrm{COCH}_{3}$ & -0.139 & 7.45 & 5.66 & 0.0059 & 0.0011 & 0.0045 & -0.0015 \\
\hline $\mathrm{CF}_{3}$ & -0.172 & 9.04 & 7.98 & 0.0056 & 0.0040 & 0.0048 & 0.0032 \\
\hline $\mathrm{COCl}$ & -0.333 & 14.33 & 12.23 & 0.0092 & 0.0047 & 0.0069 & 0.0012 \\
\hline $\mathbf{C N}$ & -0.278 & 13.05 & 11.57 & 0.0080 & 0.0053 & 0.0065 & 0.0038 \\
\hline COF & -0.334 & 13.80 & 11.84 & 0.0089 & 0.0046 & 0.0067 & -0.5605 \\
\hline $\mathrm{NO}_{2}$ & -0.368 & 16.12 & 14.58 & 0.0099 & 0.0070 & 0.0076 & 0.0047 \\
\hline NO & -0.404 & 15.46 & 13.13 & 0.0102 & 0.0049 & 0.0072 & 0.0010 \\
\hline \multicolumn{2}{|c|}{ Correlation coefficient $^{\mathrm{e}}$} & 0.986 & 0.969 & 0.987 & 0.784 & 0.982 & 0.296 \\
\hline
\end{tabular}
atom $\left(\Delta V_{N l}, \mathrm{kcal} / \mathrm{mol}\right)$ in adenine, and the shifts of Hirshfeld and $N B O$ charges $(\Delta q$, in electrons) 


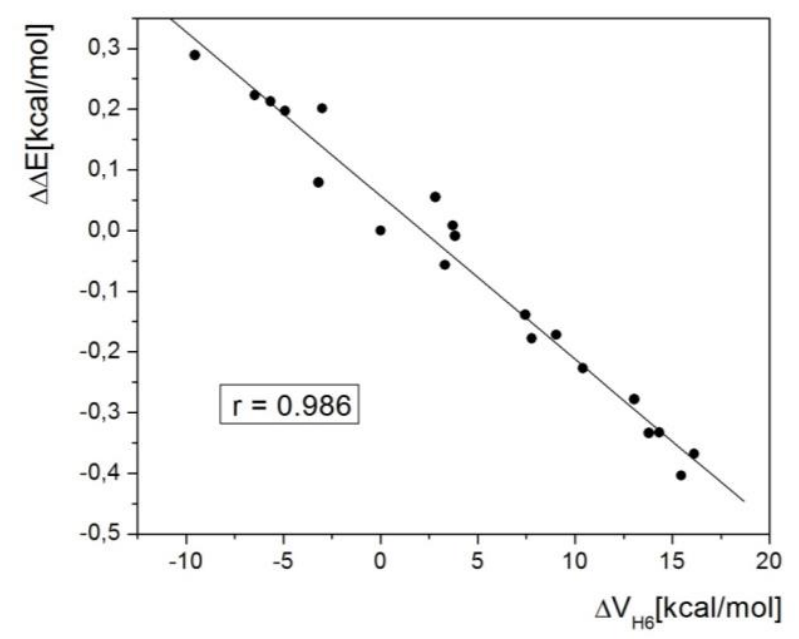

Fig. 2. Correlation between variations in interaction energy $(\Delta \Delta E)$ for substituted adenines-thymine complexes and shifts of EPN at the hydrogen atom $\left(\Delta V_{\mathrm{H} 6}\right)$ in monomeric adenines

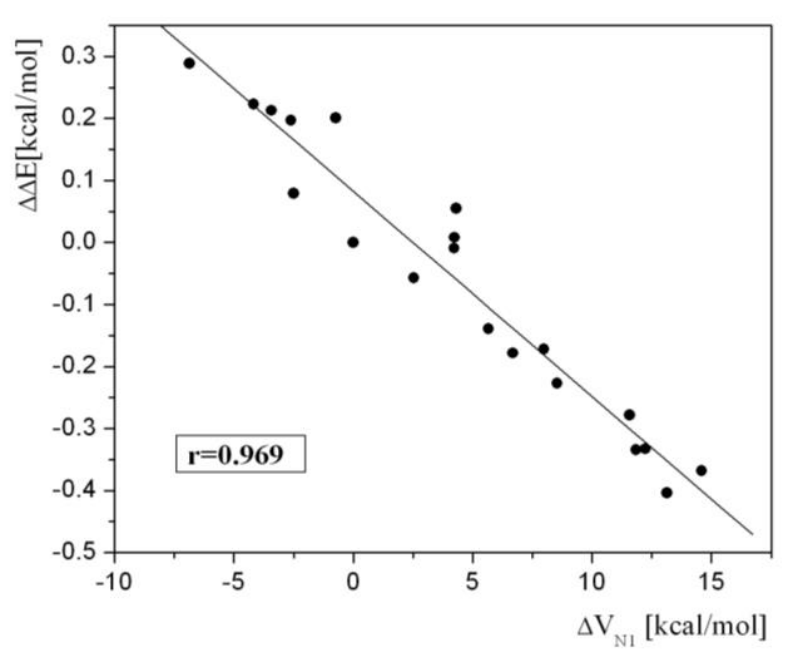

Fig. 3. Correlation between variations in interaction energy $(\Delta \Delta E)$ for substituted adenines-thymine complexes and shifts of EPN at the $\mathrm{N} 1$ nitrogen atom $\left(\Delta V_{\mathrm{N} 1}\right)$ in monomeric adenines

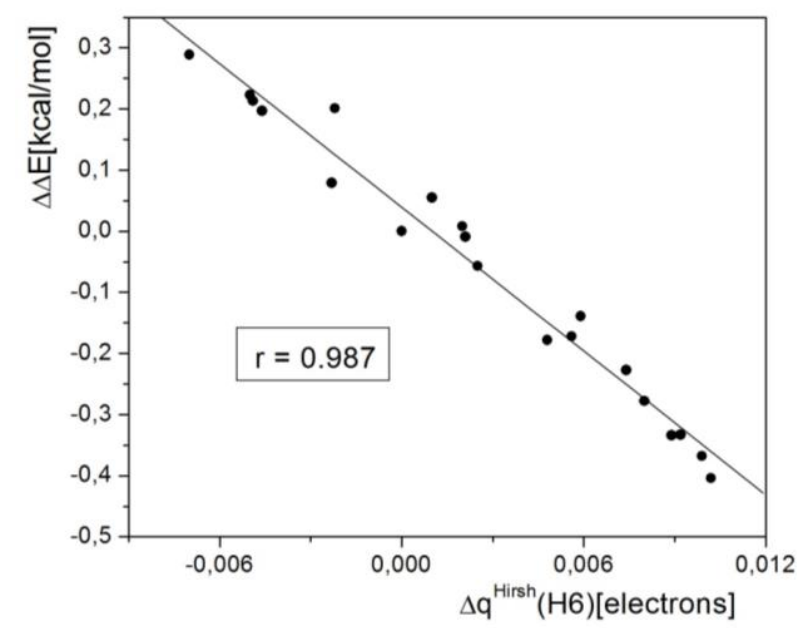

Fig. 4. Correlation between variations in interaction energies $(\Delta \Delta E)$ for substituted adenines-thymine complexes and shifts of Hirshfeld atomic charges $\left(\Delta q_{\mathrm{H} 6}{ }_{\text {Hirsh }}\right)$ in monomeric adenines
Table 3 presents the computed values of the shifts of hydrogen bonding energies $(\Delta \Delta E)$ upon substitution in position 8 of adenine, $\mathrm{N}_{6}-\mathrm{H}_{6}$ stretching frequencies in monomeric adenines, and their respective values in hydrogen-bonded complexes with thymine $\left(\boldsymbol{v}_{\mathrm{N}-\mathrm{H} \text { complex }}\right)$.

T a b le 3

B3LYP/6-311+G(2d,2p) calculated values of shifts of hydrogen bonding energies $(\Delta \Delta \boldsymbol{E}$, in $\mathrm{kcal} / \mathrm{mol})$, $\mathrm{N}_{6}-\mathrm{H}_{6}$ stretching frequencies of bond in monomeric adenines $\left(\boldsymbol{\nu}_{N-H}\right.$ monomer, $\left.\mathrm{cm}^{-1}\right)$ and their respective values in hydrogen-bonded complexes with thymine $\left(\boldsymbol{v}_{N-H}\right.$ complex, in $\left.\mathrm{cm}^{-1}\right)$.

\begin{tabular}{lccc}
\hline \hline Substituent & $\Delta \Delta \boldsymbol{E}$ & $\boldsymbol{v}_{\mathrm{N}-\mathrm{H} \text { monomer }}$ & $\boldsymbol{v}_{\mathrm{N}-\mathrm{H} \text { complex }}$ \\
\hline $\mathbf{H}$ & 0 & 3603.7 & 3410.0 \\
$\mathbf{C H}_{\mathbf{3}}$ & 0.079 & 3601.2 & 3429.3 \\
$\mathbf{O C}_{\mathbf{2}} \mathbf{H}_{\mathbf{5}}$ & 0.213 & 3595.8 & 3428.0 \\
$\mathbf{O C H}_{\mathbf{3}}$ & 0.197 & 3595.3 & 3425.5 \\
$\mathbf{O H}$ & 0.201 & 3599.9 & 3422.5 \\
$\mathbf{N H}_{\mathbf{2}}$ & 0.223 & 3559.7 & 3430.2 \\
$\mathbf{N}\left(\mathbf{C H}_{\mathbf{3}}\right)_{\mathbf{2}}$ & 0.289 & 3592.6 & 3438.3 \\
$\mathbf{F}$ & 0.055 & 3603.8 & 3404.7 \\
$\mathbf{C l}$ & 0.008 & 3605.7 & 3408.4 \\
$\mathbf{B r}$ & -0.009 & 3605.8 & 3401.0 \\
$\mathbf{C C H}$ & -0.057 & 3607.2 & 3399.5 \\
$\mathbf{C H O}$ & -0.227 & 3608.8 & 3375.3 \\
$\mathbf{C C l}$ & -0.178 & 3610.0 & 3384.9 \\
$\mathbf{C O C H}$ & -0.139 & 3610.0 & 3387.3 \\
$\mathbf{C F}$ & -0.172 & 3611.0 & 3382.9 \\
$\mathbf{C O C l}$ & -0.333 & 3607.4 & 3358.2 \\
$\mathbf{C N}$ & -0.278 & 3610.8 & 3369.1 \\
$\mathbf{C O F}$ & -0.334 & 3608.2 & 3361.4 \\
$\mathbf{N O}$ & -0.368 & 3608.2 & 3353.6 \\
$\mathbf{N O}$ & -0.404 & 3605.9 & 3352.4 \\
\hline \multicolumn{1}{c}{ Correlation coefficient } & $\mathbf{a}$ & $\mathbf{0 . 6 4 0}$ & $\mathbf{0 . 9 8 5}$ \\
\hline \hline
\end{tabular}

${ }^{\mathrm{a}}$ Correlation coefficients for dependencies between $(\Delta \Delta E)$ and the stretching frequency of $\mathrm{N}_{6}-\mathrm{H}_{6}$ bond in hydrogen-bonded base pairs adenine-thymine ( $v$ N-H complex)

The results reveal that the $\mathrm{N}-\mathrm{H}$ frequencies in the monomeric adenines do not correlate with the interaction energies for the hydrogen bonding complexes. Thus, the abilities of adinine to participate in such interaction cannot be well predicted using the values of $\mathrm{N}-\mathrm{H}$ frequencies in isolated monomers. The application of theoretical quantities, especially the $V_{\mathrm{H} 6}$ EPN values, offers much more reliable description of reactivity.

In accordance with the rule of Badger and Bauer [71] a linear dependence between the energy of hydrogen bonding and $\mathrm{N}_{6}-\mathrm{H}_{6}$ stretching frequency in the hydrogen-bonded adenine-thymine complexes is established (correlation coefficient, $r=$ 0.985). The shifts of $\mathrm{N}-\mathrm{H}$ frequencies upon com- 
plexation are intrinsically related to interactions energies, in contrast to the respective values in the isolated monomers.

The obtained good correlation between electrostatic potentials at the atoms participating in hydrogen bonding between substituted adenines and thymine provides an approach for designing biologically active substances containing the adenine moiety. As is well known, hydrogen bonding is one of the main mechanisms of ligand-bioreceptor interactions. Small changes in the structure of ligands may be essential for their biological activity.

\section{CONCLUSIONS}

Density functional theory computations on the hydrogen bonding between adenine derivatives and thymine reveal an excellent correlation between interactions energies and electrostatic potential values at the bonding atoms. The derived equation (Eqn. 2) can be employed in structure-activity studies aimed at designing ligands able to bind with a finely adjusted strength to thymine bioreceptors. Alternative quantities (atomic charges, variations in $\mathrm{N}-\mathrm{H}$ stretching frequencies in the monomer adenines) are much less successful as predictors of reactivities for hydrogen bonding between these nucleobases.

\section{REFERENCES}

[1] G. C. Pimental, A. L. McClellan, The Hydrogen Bond, Freeman, San Francisco, 1960.

[2] G. A. Jeffrey, An Introduction to Hydrogen Bonding, Oxford University Press: Oxford, 1997.

[3] J. D. Watson, F. H. Crick, Molecular structure of nucleic acids. A structure for deoxyribose nucleic acid, Nature, 171, 737-738 (1953).

[4] G. A. Jeffrey, W. Saenger, Hydrogen Bonding in Biological Structures. Springer, Berlin, 1991.

[5] J. Sponer, J. Leszczynski, P. Hobza, Electronic properties, hydrogen bonding, stacking, and cation binding of DNA and RNA bases, Biopolymers, 61, 3-31 (2001/2002).

[6] J. Sponer, J. Leszczynski, P. Hobza, Hydrogen Bonding and Stacking of DNA Bases: A Review of Quantumchemical ab initio Studies, J. Biomol. Struct. Dynamics, 14, 117-135 (1996).

[7] R. L. Baldwin, Energetics of protein folding, J. Mol. Biol., 371, 283-301 (2007).

[8] K. A. Dill, S. B. Ozkan, M. S. Shell, T. R. Weikl, The protein folding problem, Annu. Rev. Biophys. Biomol. Struct., 37, 289-316 (2008).

[9] T. N. C. Wells, A. R. Fersht, Hydrogen bonding in enzymatic catalysis analyzed by protein engineering, Nature, 316, 566-657 (1985).
[10] K. B. Schowen, H. H. Limbach, G. S. Denisov, R. L. Schowen, Hydrogen bonds and proton transfer in general-catalytic transition-state stabilization in enzyme catalysis, Biochim. Biophys. Acta, 1458, 43-62 (2000).

[11] H. Kubinyi, Hydrogen bonding: the last mystery in drug design?, in Pharmacokinetic optimization in drug research: biological, physicochemical, and computational strategies, B. Testa, H. v. Waterbeemd, G. Folkers, R. Guy, Eds., Helvetica Chimica Acta and Wiley-VCH, Zürich, 2001, pp. 513-524.

[12] M. H. Abraham, P. L. Grellier, D. V. Prior, J. J. Morris, P. J. Taylor, Hydrogen bonding. Part 10. A scale of solute hydrogen-bond basicity using $\log \mathrm{K}$ values for complexation in tetrachloromethane. J. Chem. Soc. Perkin Trans., 2, 521-529 (1990).

[13] S. P. Williams, P. B. Sigler, Atomic structure of progesterone complexed with its receptor, Nature, 393, 392396 (1998).

[14] M. H. Abraham, A. Ibrahim, A.M. Zissimos, Y. H. Zhao, J. Comer, Application of hydrogen bonding calculations in property based drug design., Drug Discov. Today., 7, 1056-1063 (2002).

[15] H. Bohm, G. Schneider, Protein-Ligand Interactions: From Molecular Recognition to Drug Design, WILEYVCH Verlag, 2003, pp. 262-266.

[16] W. Saenger, Principles of nucleic acid structure, Springer, New York, 1984.

[17] W. Arber, S. Linn, DNA modification and restriction, Ann. Rev. Biochem., 38, 467-500 (1969).

[18] C. J. Leumann, DNA Analogues: From supramolecular principles to biological properties, Bioorg.\&Med. Chem., 10, 841-854 (2002).

[19] A. Moser, R. Guza, N. Tretyakova, D. M. York, Density functional study of the influence of C5 cytosine substitution in base pairs with guanine, Theor Chem Acc, 122, 179-188 (2009).

[20] S. M. Morris, The genetic toxicology of 5-fluoropyrimidines and 5-chlorouracil, Mutat. Res., 297, 39-51, (1993).

[21] S. Kawahara, T. Uchimaru, Computer-Aided molecular design of hydrogen bond equivalents of nucleobases: theoretical study of substituent effects on the hydrogen bond energies of nucleobase pairs, Eur. J. Org. Chem., 2577-2584 (2003).

[22] P. Hozba, J. Sponer, Structure, energetics, and dynamics of the nucleic acid base pairs: nonempirical Ab-Initio calculations, Chem. Rev., 99, 3247-3276 (1999).

[23] P. Hozba, R. Zahradnik, K. Mueller-Dethlefs, The world of non-covalent interactions, Coll. Czech. Chem. Com., 71, 443-531 (2006).

[24] J. Sponer, P. Jureska, P. Hobza, Accurate interaction energies of hydrogen-bonded nucleic acid base pairs, $J$. Am. Chem. Soc., 126, 10142-10151 (2004).

[25] E. Bergmann, B. Pullman, Molecular and quantum pharmacology, Springer, Berlin, 1974.

[26] W. Saenger, Principles of nucleic acid structure; Springer: New York, 1984.

[27] A. K. Chandra, M. T. Nguyen, T. Uchimaru, T. ZeegersHuyskens, Protonation and deprotonation enthalpies of 
guanine and adenine and implications for the structure and energy of their complexes with water: Comparison with uracil, thymine and cytosine, J. Phys. Chem. A, 103, 8853-8860 (1999).

[28] S. Sharma, J. K. Lee, The acidity of adenine and adenine derivatives and biological implications. A computational and experimental gas phase study, J. Org. Chem., 67, 8360-8365 (2002).

[29] K. Morokuma, Why do molecules interact? The origin of electron donor acceptor complexes, hydrogen bonding and proton affinity, Acc. Chem. Res., 10, 294-300 (1977).

[30] P. Gilli, V. Ferretti, V. Bertolasi, G. Gilli, A novel approach to hydrogen bonding theory, in $A d v$. Mol. Struct. Res., M. Hargittai, I. Hargittai, Eds.; JAI Press, Greenwich, CT, 2, 1996, pp. 67-102.

[31] G. R. Desiraju, T. Steiner, The weak hydrogen bond in structural chemistry and biology; Oxford University Press: New York, 2001.

[32] G. Naray-Szabo, in Molecular electrostatic potentials: concepts and applications; J. S. Murray, K. Sen, Eds.; Elsevier: Berlin, 1996, pp. 333-365.

[33] C. F. Guerra, F. M. Bickelhaupt, J. G. Snijders, E. J. Baerends, The nature of the hydrogen bond in DNA base pairs: the role of charge transfer and resonance assistance, Chem. Eur. J., 5, 3581-3594 (1991).

[34] F. C. Guerra, F. M. Bickelhaupt, Charge transfer and environment effects responsible for characteristics of DNA base pairing, Angew. Chem. Int. Ed., 38, 29422945 (1999).

[35] C. F. Guerra, T. van der Wijst, F. M. Bickelhaupt, Substituent Effects on Hydrogen Bonding in Watson-Crick Base Pairs. A Theoretical Study, Struct. Chem., 16, 211221 (2005)

[36] B. Jeziorski, R. Moszynski, K. Szalewicz, Perturbation theory approach to intermolecular potential energy surfaces of Van der Waals complexes, Chem. Rev., 94, 1887-1930 (1994).

[37] M. O. Sinnokrot, C. D. Sherrill, Unexpected substituent effects in face-to-face $\pi$-stacking interactions, $J$. Phys. Chem. A, 107, 8377-8379 (2003).

[38] M. O. Sinnokrot, C. D. Sherrill, Substituent effects in $\pi$ $\pi$ interactions: sandwich and T-shaped configurations, $J$. Am. Chem. Soc., 126, 7690-7697 (2004).

[39] C. F. Guerra, T. van der Wijst, F. M. Bickelhaupt, Supramolecular switches based on the GC Watson-Crick pair. Effect of neutral and ionic substituents, Chem. Eur. J., 12, 3032-3042 (2006).

[40] F. Meng, C. Lui, W. Xu, Substituent effects of R (R = $\mathrm{CH}_{3}, \mathrm{CH}_{3} \mathrm{O}, \mathrm{F}$, and $\mathrm{NO}_{2}$ ) on the A:T and C:G base pairs: A theoretical study, Chem. Phys. Lett., 373, 72-78 (2003).

[41] F. Meng, H. Wang, W. Xu, C. Lui, Substituent effect of large conjugate groups on the DNA base pair derivatives: density functional study, Int. J. Quant. Chem., 104, 79-86 (2005).

[42] F. Meng, H. Wang, W. Xu, C. Lui, H. Wang, Theoretical study of GC+/GC base derivatives, Chem. Phys. 308 , $117-123$ (2005).
[43] C. Xue, P. L. A. Popelier, Computational study of substituents effects on the interaction energies of hydrogenbonded Watson-Crick Cytosine:Guanine base pairs, $J$. Phys. Chem. B, 112, 5257-5256 (2008).

[44] C. Xue, P. L. A. Popelier, Prediction of interaction energies of substituted hydrogen- bonded Watson-Crick Cytosine:Guanine $8 \mathrm{X}$ base pair, J. Phys. Chem. B, 113, 3245-3250 (2009).

[45] (a) A. D. Becke, Density-functional exchange-energy approximation with correct asymptotic behavior, Phys. Rev. A, 38, 3098-3100 (1998); (b) A. D. Becke, A new mixing of Hartree-Fock and local density-functional theories, J. Chem. Phys., 98, 1372-1377 (1993).

[46] Y. W. Lee Yang, R. G. Parr, Development of the ColleSalvetti correlation-energy formula into a functional of the electron density, Phys. Rev. B, 37, 785-789 (1988).

[47] (a) A. D. McLean, G. S. Chandler, Contracted Gaussian basis sets for molecular calculation. I. Second raw atoms, Z=11-18, J. Chem. Phys., 72, 5639-5649 (1980); (b) A. Krishnan, J. S. Binkley, R. Seeger, J. A. Pople, Self-consistent molecular orbital methods. XX. A basis set for correlated wave functions, J. Chem. Phys., 72, 650-655 (1980); (c) Clark T., Chandrasekhar J.; Spitznagel G. W.; Schleyer P. v. R.; Efficient diffuse function-augmented basis sets for anion calculations. III. The $3-21+\mathrm{G}$ basis set for first-row elements, Li-F, $J$. Comp. Chem,. 4, 294-301 (1983).

[48] M. J. Frisch et al. Gaussian 09 (Revision-A.02); Gaussian, Inc., Wallingford CT, 2009.

[49] S. E. F. Boys, F. Bernardi, Calculation of small molecular interactions by differences of separate total energiessome procedures with reduced errors, Mol. Phys., 19, 553-566 (1970).

[50] E. B. Wilson, Four-dimensional electron density function, J. Phys. Chem., 36, 2232-2233 (1962).

[51] P. Politzer, D. G. Truhlar, Chemical applications of atomic and molecular electrostatic potentials, Plenum Press: New York, 1981.

[52] J. S. Murray, K. Sen, Eds.; Molecular electrostatic potentials: concepts and applications; Elsevier: Amsterdam, 1996.

[53] P. Bobadova-Parvanova, B. Galabov, Ab initio molecular-orbital study of hydrogen-bonded complexes of carbonyl aliphatic compounds with hydrogen fluoride, $J$. Phys. Chem. A, 102, 1815-1819 (1998).

[54] B. Galabov, P. Bobadova-Parvanova, Molecular electrostatic potential as reactivity index in hydrogen bonding: an initio molecular orbital study of complexes of nitrile and carbonyl compounds with hydrogen fluoride, $J$. Phys. Chem. A, 103, 6793-6799 (1999).

[55] B. Galabov, P. Bobadova-Parvanova, Molecular electrostatic potential as reactivity index in hydrogen bond formation: an $\mathrm{HF} / 6-31+\mathrm{G}(\mathrm{d})$ study of hydrogen-bonded (HCN)n clusters, $n=2,3,4,5,6,7$, J. Mol. Struct., 550 551, 93-98 (2000).

[56] V. Dimitrova, S. Ilieva, B. Galabov, Electrostatic potential at atomic sites as a reactivity descriptor for hydrogen bonding. Complexes of monosubstituted acetylenes and ammonia, J. Phys. Chem. A, 106, 11801-11805 (2002). 
[57] B. Galabov, P. Bobadova-Parvanova, S. Ilieva, V. Dimitrova, The electrostatic potential at atomic sites as a reactivity index in the hydrogen bond formation, J. Mol. Struct. Theochem, 630, 101-112 (2003).

[58] B. Galabov, D. Cheshmedzhieva, S. Ilieva, B. Hadjieva, Computational study of the reactivity of $\mathrm{N}$-phenylacetamides in the alkaline hydrolysis reaction, J. Phys. Chem. A, 108, 11457-11462 (2004).

[59] B. Galabov, S. Ilieva, H. F. Schaefer, An efficient computational approach for the evaluation of substituent constants, J. Org. Chem., 71, 6382-6387 (2006).

[60] B. Galabov, S. Ilieva, B. Hadjieva, Y. Atanasov, H. F. Schaefer, Predicting reactivities of organic molecules. Theoretical and experimental studies on the aminolysis of phenyl acetates, J. Phys. Chem. A, 112, 6700-6707 (2008).

[61] B. Galabov, V. Nikolova, J. J. Wilke, H. F. Schaefer, W. D. Allen, Origin of the $\mathrm{S}_{\mathrm{N}} 2$ benzylic effect, J. Am. Chem. Soc., 130, 9887-9896 (2008).

[62] B. Galabov, S. Ilieva, G. Koleva, W. D. Allen, H. F. Schaefer, P. v. R. Schleyer, Structure-reactivity relationships for Aromatic molecules: Application of the electrostatic potential at nuclei and electrophile affinity electronic indices, WIREs Comput. Mol. Sci., 3, 37-55 (2013).

[63] B. Galabov, V. Nikolova, S. Ilieva, Does the molecular electrostatic potential reflect the effects of substituents in aromatic systems?, Chem.-Eur. J., 19, 5149-5155 (2013).

[64] V. Nikolova, S. Ilieva, B. Galabov, H. F. Schaefer III Experimental Measurement and Theory of substituent effects on $\pi$-hydrogen bonding: Complexes of substitut- ed phenols with benzene, J. Org. Chem., 79, 6823-6831 (2014).

[65] C.-H. Wu, B. Galabov, J. I.-C. Wu, S. Ilieva, P. v. R. Schleyer, W. D. Allen, Do $\pi$-Conjugative Effects facilitate $\mathrm{S}_{\mathrm{N}} 2$ reactions?, J. Am. Chem. Soc., 136, 3118-3126 (2014).

[66] K. Kitaura, K. Morokuma, A new energy decomposition scheme for molecular interactions within the HartreeFock approximation, Int. J. Quant. Chem., 10, 325-340 (1976).

[67] K. Morokuma, Molecular-orbital studies of hydrogen bonds. 3. C-O..... H-O hydrogen bond in $\mathrm{H}_{2} \mathrm{CO} \ldots . . \mathrm{H}_{2} \mathrm{O}$ and $\mathrm{H}_{2} \mathrm{CO} \ldots 2 \mathrm{H}_{2} \mathrm{O}, J$. Chem. Phys., 55, 1236-1248 (1971).

[68] H. Umeyama, K. Morokuma, The origin of hydrogen bonding: An energy decomposition study, J. Am. Chem. Soc., 99, 1316-1332 (1977).

[69] (a) A. E. Reed, L. A. Curtiss, F. Weinhold, Natural population analysis, Chem. Rev., 88, 899-926 (1988); (b) J. E. Carpenter, F. Weinhold, Intermolecular interactions from a natural bond orbital, donor-acceptor viewpoint, J. Mol. Struct. (Theochem), 169, 41-62 (1988).

[70] F. L. Hirshfeld, Bonded-atom fragments for describing molecular charge densities, Theor. Chem. Acc., 44, 129138 (1977).

[71] R. M. Badger, S. H. Bauer, Spectroscopic studies of the hydrogen bond. II. The shift of the $\mathrm{O}$ [single bond] $\mathrm{H}$ vibrational frequency in the formation of the hydrogen bond, J. Chem. Phys., 5, 839-841 (1939). 
